Article

\title{
Research in Sustainable Tourism: A Longitudinal Study of Articles between 2008 and 2017
}

\author{
Jianwei Qian ${ }^{1}$ (D), Huawen Shen ${ }^{2, *}$ and Rob Law ${ }^{3}$ \\ 1 Foreign Languages Teaching Centre, Communication University of Zhejiang, 998 Xueyuan Street, \\ Hangzhou 310018, China; 821223168@163.com \\ 2 Faculty of International Tourism and Management, City University of Macau, Avenida Padre Tomas Pereira \\ Taipa, Macau 999078, China \\ 3 School of Hotel \& Tourism Management, Hong Kong Polytechnic University, 17 Science Museum Road, \\ Hong Kong 999077, China; rob.law@polyu.edu.hk \\ * Correspondence: shenhuawen1980@hotmail.com; Tel.: +853-8590-2509
}

Received: 21 December 2017; Accepted: 15 January 2018; Published: 26 February 2018

\begin{abstract}
The influence of tourism on the environment has led to research on the development of sustainable tourism. Scholars from popular destinations and their governments are actively conducting sustainable tourism research, and their contributions to the field have achieved global renown. Without data from the natural sciences, knowledge from tourism dominates this area. This work utilizes content analysis to systematically review these studies to present the current state of existing research with the aid of visualization tools. The findings delineate the development of research on sustainable tourism in terms of collaboration, impact, knowledge base, and thematic coverage. Six major themes are selected to showcase recent trends in sustainable tourism research and guide future studies. Accordingly, this study can contribute to the development of sustainable tourism research and guide industry practices.
\end{abstract}

Keywords: sustainable tourism research; longitudinal study; Journal of Sustainable Tourism

\section{Introduction}

In recent years, tourism has boomed into an eye-catching industry across the world because of the significant role it plays in stimulating consumption, promoting trade, and enhancing international communication. Many countries in Asia, Latin America, and Sub-Saharan Africa place a huge weight on the economic effects of tourism [1]; however, the industry's influence on the environment should not be overlooked. Recognizing this, Ceballos Lascurain of the International Union for Conservation of Nature proposed the concept of sustainable tourism in 1983. The World Tourism Organization enriched the concept in 1998 through its explanation towards sustainable tourism, and sustainable tourism is defined as tourism development that can meet the demand of both tourists and host communities whilst preserving and improving the opportunity for future development [2]. As a response to and reflection of the damage mass tourism brings to the ecological environment, sustainable tourism has aroused the attention of all tourism stakeholders. According to Beaumont, tourists with eco-awareness tend to become the major tourism market because this type of tourist travels more frequently than others [3]. Therefore, sustainable tourism has taken an increasingly prominent position in the entire market [4]. Various government policies and multi-level conferences have been proposed, and different associations have been organized to promote sustainable tourism. Tourism scholars have fulfilled their roles as forerunners in the campaign by conducting studies to tackle sustainability from different perspectives, and their findings have made significant contributions to the promotion of sustainable tourism. 
According to Buckley, over 5000 articles on sustainable tourism have been published around the world between 1990 and 2012, establishing the prevalence of sustainable tourism as a research topic [5]. Nevertheless, a comprehensive and systematic analysis of this research area has been undertaken rarely in the tourism academia [6], despite the importance of conducting a timely, state-of-the-art review of academic work. Besides this, the increasing number of studies on sustainable tourism and the accumulated importance from this area designate that a state-of-the-art examination of prior studies in this area is important. Actually, this kind of research has the potential to provoke the development of knowledge and the shifting of paradigms in a particular research area [7]. First-tier tourism journals have also recognized the importance of such review studies and have published more of these articles accordingly [7]. To determine the status quo of sustainable tourism research, the present study attempts to identify the trends in research and scholarship through bibliometric and thematic analyses. The findings can enlighten the academia and reveal more potential research ideas in sustainable tourism, thus guiding other stakeholders to take the necessary actions in ensuring that tourism development heads in a sustainable direction.

\section{Materials and Methods}

To show a panoramic view of sustainable tourism research, articles concerning sustainable tourism were extracted from the online database, and content analysis was used to conduct bibliometric and thematic analyses along with the detection of the knowledge base for the field.

The Journal of Sustainable Tourism (JST) was chosen as the source of the articles selected for examination. Founded in 1993, JST now ranks among the first-tier tourism journals that aim to promote critical and innovative thinking with regard to the relationship between sustainability and tourism. According to its website, JST accepts articles from interdisciplinary studies to ensure a multi-perspective examination of sustainable tourism that takes into account its social, economic, cultural, and environmental aspects. The journal held an impact factor of 2.978 in 2016, ranking in the first quartile of tourism journals. This ranking means JST has enjoyed immense popularity among the academia and has cemented its standing as a high-quality journal. Moreover, JST is the only journal in tourism that puts the promotion of sustainable tourism at the forefront of its mission. Hence, JST is suitable to represent the status quo and the development of sustainable tourism research. To better represent current conditions and trends, only articles published after JST became a Social Sciences Citation Index (SSCI)-indexed journal in 2008 were downloaded, as most review studies consider the SSCI as a symbol of journal quality and only articles published in SSCI-indexed journals are examined for further analysis [8,9]. Only full-length research articles were selected because they provide more information regarding research methods, theoretical concepts or frameworks, and managerial guidance [10]. The study examined a total of 599 articles published by the journal from 2008 to 2017 . These 599 articles have been cited 1694 times in total, with each article receiving 2.83 citations on average. It should be noted that JST does not have a monopoly of publishing studies concerning sustainable tourism, but JST really publishes the largest number of articles in this area and can be regarded as an excellent platform for researches to present and exchange ideas in sustainable tourism [11]. Meanwhile, JST is proven to be successful in setting up a distinct identity in tourism academia, namely its ability in driving, enabling and shaping sustainable tourism development among both the academic and business practitioners [11].

Content analysis was utilized to analyze the chosen articles because it can guarantee the quality and completeness of extracted information and is widely used in review studies $[7,12,13]$. Content analysis can also assist a clearer categorization of examined phenomena or events in terms of pre-defined concepts in order to better interpret these phenomena or events for research purposes [9]. Xiao and Smith state that the use of content analysis to explore academic articles can offer solid evidence of the progress of knowledge in a specific field together with the identification of research methodologies [14]. Therefore, content analysis has been deployed in many tourism review studies $[7,10,12,13]$ and is suitable for the analysis in this study as well. Two scientometric 
programs, VOSviewer and CiteSpace, were also utilized to help visualize some of the results. All in all, the following aspects of the selected articles were analyzed: collaboration analysis, impact analysis, knowledge base, and thematic coverage. These aspects were deemed sufficient to address the research questions proposed in the Introduction.

\section{Results}

\subsection{Collaboration}

The collaboration analysis of JST articles was conducted from two dimensions: country collaboration and institute collaboration. This process was completed with the assistance of VOSviewer.

Figure 1 illustrates the countries where the authors and contributors of JST worked when the articles were published and the collaboration network between countries. In total, authors from 45 countries participated in studies concerning sustainable tourism. The size of the node represents the number of articles from the country, revealing that authors from the US and Australia published the highest number of articles, followed by China and the UK. As illustrated by the thickness of the links between the two countries, China and the US have formed a close collaboration network, as have Australia and the UK. Moreover, Australia and China have a close relationship with the other top countries, but there is no link between the US and the UK. Most popular tourist destinations contribute to a large part of the sustainable development of tourism from an academic perspective. According to the 2016 United Nations World Tourism Organization (UNWTO) Annual Report [15], the world's top tourist destinations in 2015 were France, USA, Spain, China, and Italy. However, France, the top destination in 2015, does not have a presence in the figure. This outcome may be attributed to France having done well to keep its tourism sustainable. Nevertheless, sustainability is a perpetual goal that warrants continuous efforts, even from the French academia.

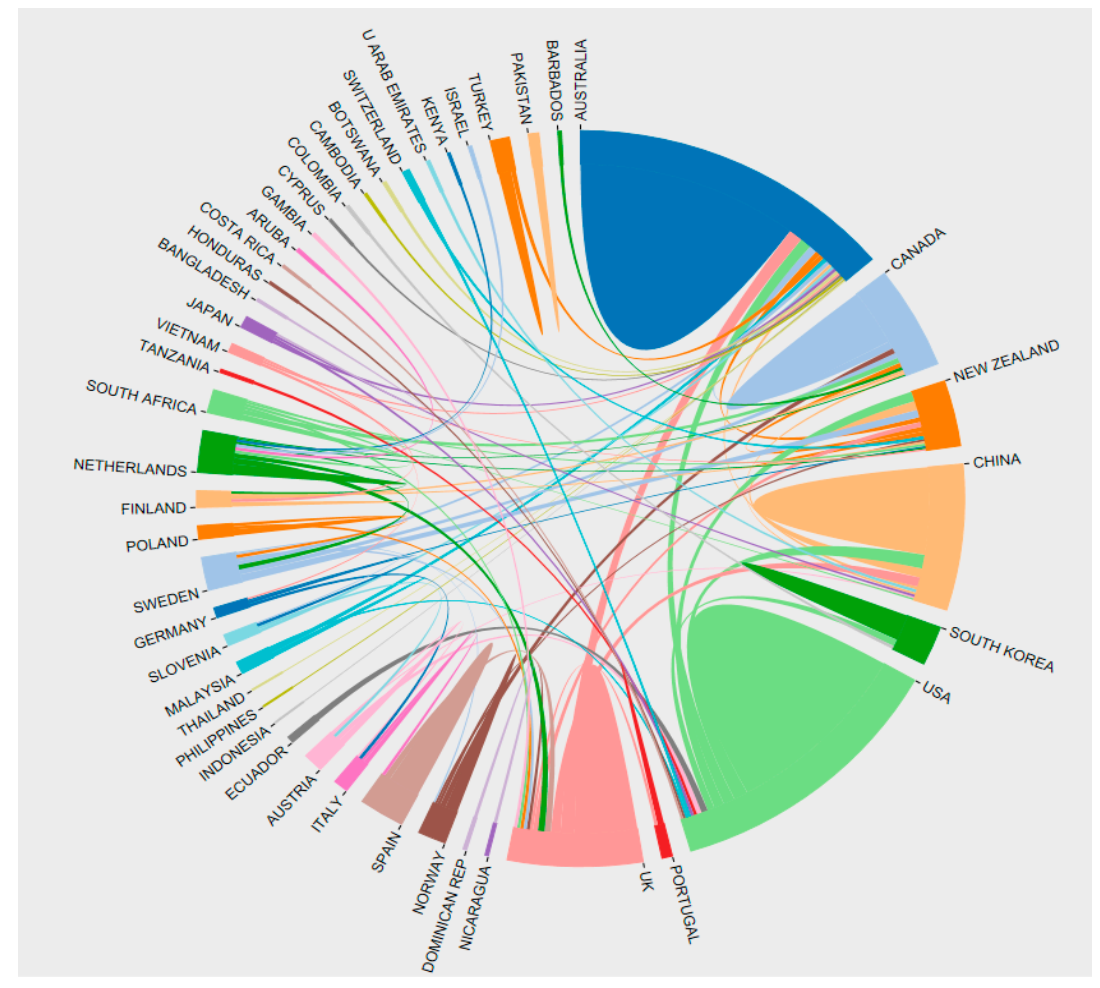

Figure 1. Country Collaboration of Authors in JST.

Figure 2 depicts the institute collaboration, which reveals that the majority of institutes involved in JST studies have established a close collaboration network, with most institutes located within a larger 
network. The red color in the figure represents the proximity of the institutes in a cluster. Four tight collaborations are identified, each containing between two and four institutes. The four major institutes in the largest cluster are universities in Australia, indicating that Australian universities have set up their own research network in their country. The other two large clusters are mainly composed of universities from Europe and the USA. This finding may describe how the collaboration of sustainable tourism research has a distinctive geographical feature, and that universities with short geographical distances tend to cooperate more in sustainable tourism research. This phenomenon, logically, should arise from the fact that universities sharing similar geographical locations are more familiar with their research environment and may generate more research insights. Similar collaboration patterns can also be found in other tourism and hospitality research areas [16]. However, the University of Oulu from Finland and Colorado State University from the USA have conducted sustainable tourism studies unaided.

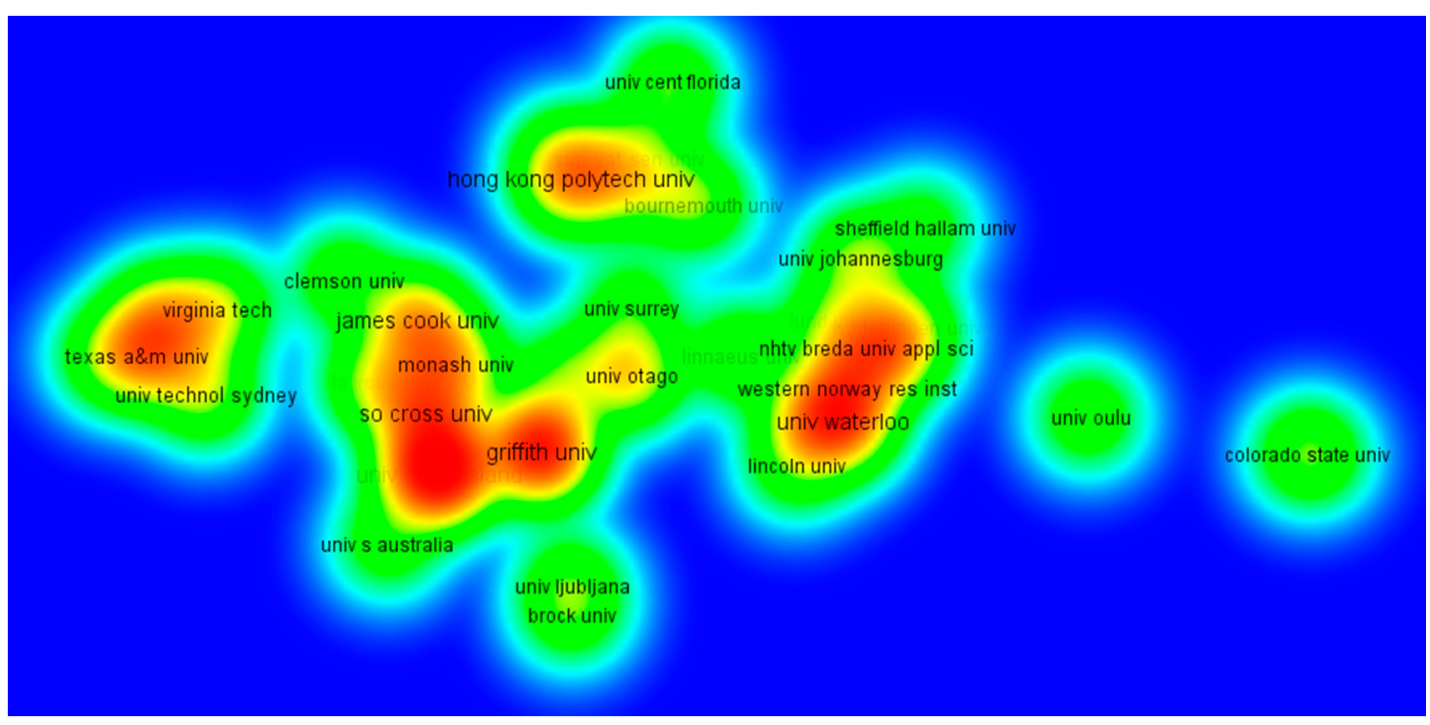

Figure 2. Institute Collaboration of Authors in JST.

\subsection{Impact}

Institute impact and author impact are examined to study sustainable tourism research from the impact perspective. All the impact figures were taken from the Web of Science.

As shown in Table 1, University of Waterloo occupies the first position in both the number of total citations and the citations from first author articles, signifying the university's importance in sustainable tourism studies. Five of the top 10 institutes that received the largest number of total citations are from Australia, namely, Monash University, James Cook University, Griffith University, South Cross University, and University of Queensland. These universities rank from No. 2 to No. 7, indicating their relatively high positions even among the top institutes and the leading role that Australian universities play in the field of sustainable tourism research. Such a phenomenon may be closely related with the attractions of Australia, which mainly involve natural landscapes that require special protection to guarantee sustainability. Australian researchers have realized this demand and conduct relevant studies accordingly. However, in terms of the average citation per first author article, Australian universities fall behind the other five universities. Special attention should be paid to Texas A\&M University, which only has seven first authors but generates the highest number of citations per first author article. University of Canterbury also has a great impact in this area, as evidenced by its top ranking in the average number of citations per article and its second-place ranking in average number of citations per first author article. This result may be due to the high quality of studies from these two universities, but it may also be attributed to the fact that their research foci are in line with 
the trends in sustainable tourism, and the proposed theoretical frameworks are quite practical that can be widely applied in other sustainable tourism studies.

Table 1. Institute Impact of Articles in JST.

\begin{tabular}{|c|c|c|c|c|c|c|}
\hline Institute & $\begin{array}{c}\text { Number of } \\
\text { Total Citations }\end{array}$ & $\begin{array}{l}\text { Average Citation } \\
\text { Per Article }\end{array}$ & $\begin{array}{c}\text { Number of } \\
\text { Articles }\end{array}$ & $\begin{array}{l}\text { Number of Citations from } \\
\text { First Author Articles }\end{array}$ & $\begin{array}{l}\text { Average Citation Per } \\
\text { First Author Article }\end{array}$ & $\begin{array}{c}\text { Number of } \\
\text { First Authors }\end{array}$ \\
\hline U. of Waterloo & 137 & 5.71 & 24 & 131 & 7.71 & 17 \\
\hline Monash U. & 127 & 6.35 & 20 & 44 & 4.40 & 10 \\
\hline Griffith U. & 117 & 2.79 & 42 & 87 & 3.63 & 24 \\
\hline South Cross U. & 95 & 4.75 & 20 & 56 & 4.67 & 12 \\
\hline Texas A\&M U. & 90 & 6.43 & 14 & 76 & 10.86 & 7 \\
\hline U. of Queensland & 81 & 2.61 & 31 & 48 & 2.82 & 17 \\
\hline Leeds Metropolitan U. & 73 & 6.08 & 12 & 42 & 6.00 & 7 \\
\hline
\end{tabular}

Note: U., University.

With regard to the most influential authors (Table 2), 10 leading authors are from nine universities, with both Bob McKercher and Rob Law hailing from The Hong Kong Polytechnic University. Daniel Scott from University of Waterloo tops the list in terms of the number of total citations and the number of citations from first author articles. His first article in JST, which examined the carbon cost of polar bear viewing tourism, was published in 2010, and all his following publications have centered on climate change and tourism. Although JST only published three articles by Bill Bramwell of Sheffield Hallam University during the examined period, he received the highest number of average citations per article and average citations per first author article. His research foci are tourism policy and sustainable tourism. Amid the top authors, six are editorial board members of JST, and Bill Bramwell is also the founding editor of the journal. The findings demonstrate the importance and vitality of these researchers in sustainable tourism from another perspective. A total of nine out of the 10 authors are western researchers, showing the strong influence of western academia on studies in sustainable tourism studies from the perspective of JST. However, eastern scholars may have published related studies in other tourism journals or non-English journals, hence this finding is only applicable to studies on JST.

Table 2. Author Impact of Articles in JST.

\begin{tabular}{|c|c|c|c|c|c|c|}
\hline Author & $\begin{array}{l}\text { Number of } \\
\text { Total Citations }\end{array}$ & $\begin{array}{l}\text { Average Citation } \\
\text { Per Article }\end{array}$ & $\begin{array}{l}\text { Number of } \\
\text { Articles }\end{array}$ & $\begin{array}{l}\text { Number of Citations from } \\
\text { First Author Articles }\end{array}$ & $\begin{array}{l}\text { Average Citation Per } \\
\text { First Author Article }\end{array}$ & $\begin{array}{l}\text { Number of First } \\
\text { Author Articles }\end{array}$ \\
\hline Scott, D. & 97 & 13.86 & 7 & 87 & 17.40 & 5 \\
\hline Hall, C.M. & 71 & 7.10 & 10 & 33 & 11.00 & 3 \\
\hline Bramwell, B. & 59 & 19.67 & 3 & 59 & 29.50 & 2 \\
\hline Prideaux, B. & 52 & 10.40 & 5 & 0 & 0.00 & 0 \\
\hline Jamal, T. & 50 & 8.33 & 6 & 38 & 12.67 & 3 \\
\hline McKercher, B. & 46 & 9.20 & 5 & 45 & 11.25 & 4 \\
\hline Law, R. & 29 & 14.50 & 2 & 0 & 0.00 & 0 \\
\hline
\end{tabular}

\subsection{Knowledge Base}

According to the principle of Scientometrics, the knowledge base of a field can be identified by investigating the major discipline publications that the field has been built upon [17]. The examination of the most-cited journals tends to fulfill this function. There are 19,950 distinct references in the JST articles. Table 3 lists the top cited journals, along with the journal impact factor (JIF) in 2016, the position of each journal in the journal quartile list, and the total number of cited references (CR) from the journal. 
Table 3. Most Cited Journals by Articles in JST.

\begin{tabular}{ccccc}
\hline Rank & Journal & Impact Factor & JIF Quartile & CR \\
\hline 1 & Journal of Sustainable Tourism & 2.978 & Q1 & 1033 \\
2 & Tourism Management & 4.707 & Q1 & 553 \\
3 & Annals of Tourism Research & 3.194 & Q1 & 479 \\
4 & Journal of Travel Research & 4.564 & Q1 & 336 \\
5 & Current Issues in Tourism & 2.451 & $\mathrm{Q} 2$ & 284 \\
6 & International Journal of Tourism Research & 1.857 & $\mathrm{Q} 2$ & 211 \\
7 & Tourism Geographies & 1.663 & $\mathrm{Q} 2$ & 173 \\
8 & Journal of Ecotourism & $/$ & 118 \\
9 & Tourism Recreation Research & $/$ & 116 \\
10 & Ecological Economics & 2.965 & $\mathrm{Q} 1$ & 111 \\
\hline \multicolumn{5}{c}{ Note: JIF, journal impact factor; CR, cited references. }
\end{tabular}

Articles in JST prefer to cite other articles in JST, followed by the three other top tourism journals. These four journals are the only journals that focus on tourism alone in the first quartile of Clarivate Analytics' ranking of journals on hospitality, leisure, sports and tourism. Moreover, eight of the top cited journals are indexed in SSCI, proving that JST studies mainly draw upon other high-quality research. A total of nine of the 10 journals in the list are tourism journals, indicating that the knowledge base of JST studies largely derives from the field of tourism. The only exception is Ecological Economics, which is an interdisciplinary journal covering both ecology and economics. No hospitality journal enters the top, though hotels have also become a major source of pollution and are involved in the pursuit of energy conservation. It is entirely possible that several studies in JST are concerned with hospitality, but due to the importance of sustainability, top hospitality journals should also shoulder their responsibility to disseminate sustainable awareness among the academia and the industry. In addition, very limited journals from other fields, especially natural sciences, have become the knowledge base of JST studies. However, knowledge of sustainability, including the criteria of sustainability, measurement of environmental change, and approaches to develop sustainability, is geared toward the natural sciences. Hence, future studies about sustainable tourism should also take knowledge from other fields into consideration.

\subsection{Thematic Coverage}

Every article is written based on many references that form the basis of these articles. Therefore, an examination of the cited references of JST articles could provide information regarding the research themes of JST articles or what they are trying to accomplish. All the information from the references is input into CiteSpace, and nine distinctive themes are identified in Figure 3. Some clusters have overlaps because they share common elements within the cluster. Based on Chen [18], the value for Modularity $\mathrm{Q}$ is 0.7965 , which indicates a significant difference between each cluster. Meanwhile, the value of the Mean Silhouette is 0.5196 , which is larger than 0.5 , meaning that the achieved clustering result is reasonable.

In the result, \#3 "protected area" is the place where sustainable tourism is conducted, and \#6 "ecotourism" is synonymous with sustainable tourism. Both concepts are the key components of every activity in sustainable tourism and are widely spread in JST articles. Meanwhile, sustainable tourism development (\#4) is the perpetual theme of sustainable tourism studies. Hence, these three clusters are not discussed independently, whereas the other six clusters are explored one by one to completely showcase the major themes of sustainable tourism research.

The theme for \#0 is climate change, which shows the popularity of the topic in JST studies. It has even been identified as the major reason tourists conduct last chance tourism [19], but tourism businesses seldom mention this concept in their daily operations [20,21]. Hence, tourism has actually become a major contributor of greenhouse gas emissions worldwide [22] despite the many forms of tourism, such as coastal tourism [23], ski tourism [24,25], and animal watching tourism [26,27], 
actually being vulnerable to climate change because of these emissions. In 2007, the UN organized the Climate Change Conference and 196 countries signed the Paris Climate Change Agreement, verifying the importance of climate change to the whole world. Thus, it is high time that tourism considers what can be done in this campaign [28].

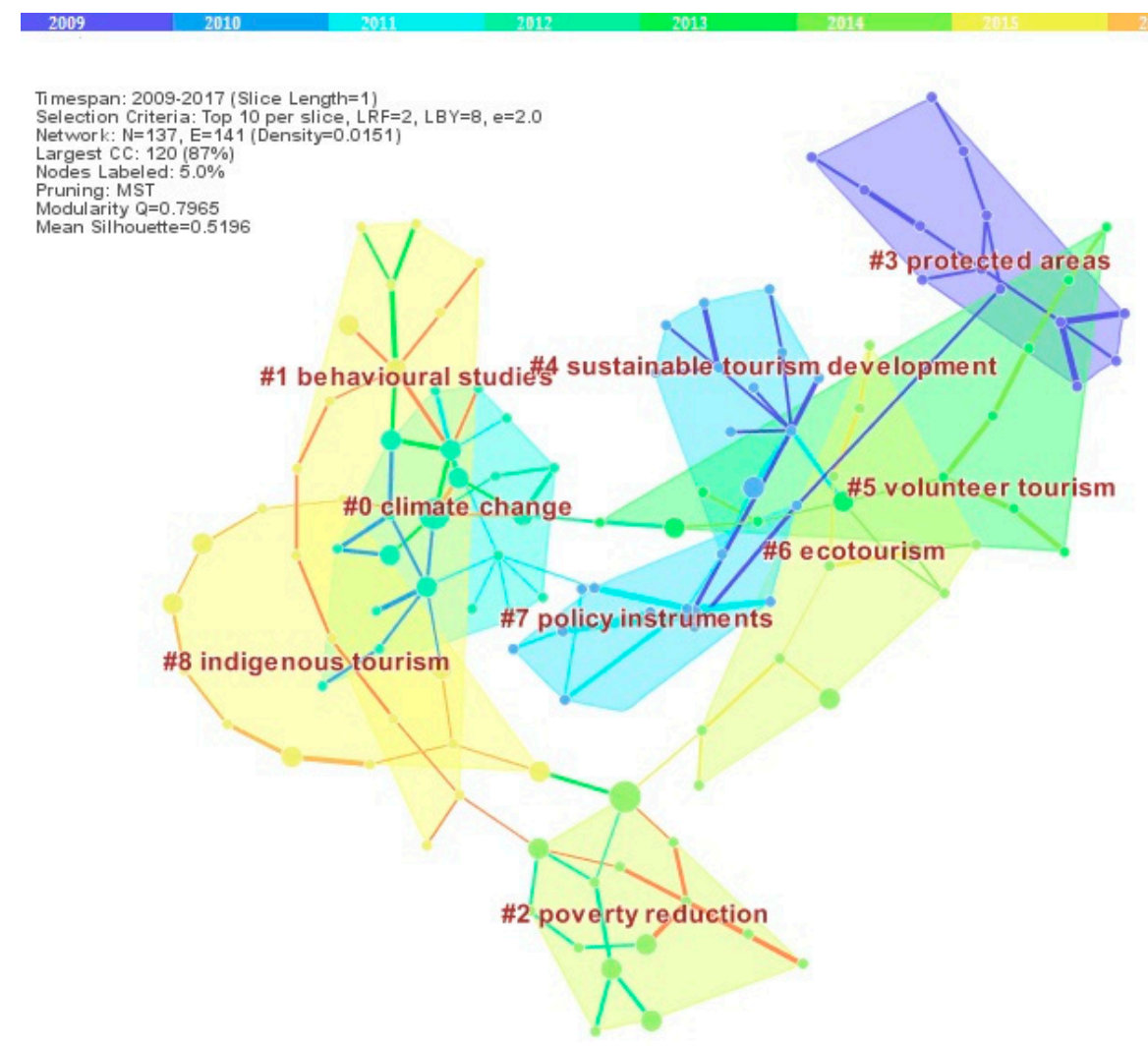

Figure 3. Visualization of the Major Themes in JST Articles.

Major studies have examined the climate change that tourism brings from the perspective of tourists. For example, studies have been conducted on the difficulty of adopting low-carbon vacations $[29,30]$, the profile of travelers who have actually paid for the carbon emissions generated by their air travel [31,32] and those who intend to pay [33], the role of values in influencing tourists to reduce air travel [34], and the reasons behind their reluctance to change their behavior to better address the issue of climate change [35]. However, climate change remains an overlooked phenomenon for large quantities of tourists from developing countries [36]. Tourist air travel has clearly become the major research subject under this theme, as air travel emits more carbon emissions and exerts a more direct impact on climate change compared to other modes of transport.

Aside from the reasons that Scott proposes regarding why the tourism industry should address climate change [37], other groups of studies are concerned about how the industry can promote sustainable tourism, such as the key ways to do discourse promotion [38], the effectiveness of what the industry has done to foster awareness among tourists [39], and the useful adoption of technical developments [40]. Only one study relates to the hospitality area in which a conceptual model for restaurants is developed to carry out energy conservation and carbon reduction [41].

The theme for \#1 is behavioral studies. Research under this theme apparently focuses on examining the sustainable behavior that tourists exhibit while traveling. Hence, various models have been formed to fulfill this objective, such as the three-gear model used to investigate tourists' choice of sustainable modes of transportation [42], and a hypothesized conceptual model to examine tourist behavior toward slow tourism [43]. The development of sustainable tourism is bound to gain support 
from all stakeholders and influence the supportive behavior of residents [44], the policy-making behavior of government officials [45], as well as the industry and academia's behavioral change from solely marketing to marketing sustainably [46]. Moreover, place attachment is affirmed to be crucial in cultivating the eco-friendly behavior of tourists $[47,48]$.

Within behavioral studies, the hotel industry is another important target to examine. The proactive green marketing behavior of hotel managers has been associated more with the hotels' profile rather than the managers' own attitudes toward sustainable tourism [49]. A positive relationship is found between a hotel's green image and the customers' favorable behavioral intentions [50], and customers are happier staying in a hotel because of its pro-environment image [51]. Bohdanowicz et al. analyze the performance of Hilton hotels in terms of environmental protection, highlighting the importance of corporate social responsibility and human resource management in guiding hotels to conduct sustainable management practices [52].

Studies in cluster 2 focus on poverty reduction. Tourism has long been regarded as a way to alleviate poverty in economically less developed countries. Snyman confirms that ecotourism has contributed to the economic development and environmental protection of many African countries [53]. Owing to the freedom they enjoy, tour operators are said to be more effective in reducing poverty in Ecuador than some development organizations [54]. Tucker and Boonabaana argue that women can also contribute to tourism development and help reduce poverty, but the approach to motivate women should be different from men [55]. The Netherlands is the only developed country examined in this cluster, in which a five-stage tourism development plan to help alleviate poverty exists [56].

However, several problems emerge with the development of tourism. Nelson points out that tourism development in Tanzania was launched by the government or other elite groups to enhance their control of natural resources rather than as a way to help the poor [57]. Truong, Hall, and Garry verify that the tourism sector in Vietnam mainly benefits the non-poor citizens and tour operators, while the poor achieve very little because of the lack of capital and the language barrier [58]. The use of community-based tourism to develop the economy of rural-peasant areas is affirmed to have several major limitations that influence its actual effects [59]. Two review studies have been conducted. Spenceley and Meyer analyzed and contrasted the effectiveness of theory and practice in tourism and poverty alleviation [60]. By contrast, Medina-Munoz, Medina-Munoz, and Gutierrez-Perez examined studies about the influence of tourism on poverty reduction in terms of bibliometric and thematic analyses and proposed a conceptual framework for guiding future empirical research in this area [61].

Sustainable tourism is not limited to the proper utilization of the environment but also linked to cultural, social, and economic sustainability. Volunteer tourism is an increasingly popular travel mode proven to enhance cross-cultural understanding [62-64] and further promote the economy of the host region [65]. Hence, volunteer tourism becomes the theme of cluster 5 in sustainable tourism studies. To fully present the power of volunteer tourism, several key factors have been identified, including the participation of community stakeholders [66], the proper design of volunteer activities by organizations $[67,68]$, and different positioning strategies for international and in-country volunteer activities [69]. Distance and time are also validated to be major barriers that keep tourists from participating in volunteer tourism [70]. Lupoli et al. develop a low-cost and rapid appraisal tool for evaluating the impact of volunteer tourism and confirm the applicability of the tool in host communities of volunteer tourism [71]. Although volunteer tourism is mainly beneficial to the society, it is sometimes misused by the industry to simply promote tourism activities without any cultivation of responsibility among tourists [72].

Sustainable tourism development is not possible without proper management from the government; hence, $\# 7$ is about policy instrument. From the name of this cluster, the articles involved are mainly concerned with the proposition of various policy instruments, such as the subsidiarity of tourism governance [73] and pro-poor tourism policy [74]. Policy has also been validated as important for the development of indigenous tourism $[75,76]$ and the industry's response to environmental change [77]. Hall establishes a typology of governance in tourism that helps analyze tourism policy [78], 
while Yuksel et al. believe that the statement of ministers is a useful instrument for presenting sustainability in tourism from the policy perspective [79].

Indigenous tourism forms the last cluster. Indigenous tourism has become an important form to develop tourism in many countries where sustainability needs to be addressed [80]. Weaver proposes a six-stage model to explain the evolution of indigenous tourism [81]. However, despite the popularity of indigenous tourism, operators in Australia still consider what they are doing to be for economic purposes and not related to sustainable tourism [82]. Moreover, various issues arise in communities where indigenous tourism is developing quickly, such as the protection of heritages [83], the upholding of the rights of indigenous populations [84], and the preservation of indigenous culture [85]. Empowering the residents in indigenous areas with knowledge, economic resources, and communication skills has been suggested to help sustain the development of indigenous tourism [86]. Integrating indigenous values with capitalism through tourism is demonstrated to be another way to realize indigenous sustainable development [87].

\section{Discussion and Conclusions}

Research on sustainable tourism is gaining more attention from the tourism academia. Scholars from major destinations worldwide have made due efforts to address issues emerging in their respective continents, and the findings from these studies have generated both theoretical contributions and managerial implications for sustainable tourism. Tourism is an integrative reflection of economic, societal, and cultural phenomena, which indicate that sustainable tourism research should be comprehensive and multi-dimensional. The present study explores the current condition of sustainable tourism research in terms of bibliometric and thematic analyses.

Collaboration analysis affirms the scholarly participation of global destinations and identifies that the geographical factor enables greater cooperation among scholars from short distances. Universities in Australia, the US, and Europe have established three large collaboration networks to carry out sustainable tourism research. Meanwhile, bibliometric data prove that scholars based in Australia and the US have been found to be the most influential writers in this field because of the high citation rate. Scholars from the University of Waterloo (Canada), The Hong Kong Polytechnic University (China), and Leeds Metropolitan University (UK) make great contributions to this area because most highly cited papers are from these universities. The key scholars are quite active in this area because they both contribute to most of the research articles and citations and act as editorial board members for JST. It may indicate that these key scholars concentrate on doing sustainable tourism studies and are familiar with the style of JST; hence, they can become editorial board members of the journal and contribute to the journal's long-term development. With regard to the knowledge base, knowledge from tourism, especially articles from top tourism journals, forms the basics of sustainable tourism research, whereas knowledge from natural sciences does not take the central position. Moreover, hotel literature has been shown to generate less influence on sustainable tourism research.

The six major themes of sustainable tourism research are generated based on the references of JST articles: climate change, behavioral studies, poverty reduction, volunteer tourism, policy instrument, and indigenous tourism. These themes are prevalent in the examined period, and this study determines what scholars are scrutinizing within each theme. The result reveals both the current situation and the possibilities for future research. For example, both the tourism sector and hotel sector have been examined frequently, but another growing sector, conventions and events (C\&E), remains under-researched, despite $C \& E$ having brought much revenue to a destination. The insufficient understanding and lack of knowledge on C\&E's ecological role in the current industry have been identified [88]. Thus, future studies can explore issues in C\&E, ranging from climate change to policy instruments.

Several limitations exist in the current study. First, only articles from JST are examined for the research, while in reality, a majority of tourism journals examine sustainable tourism. To a certain extent, this limitation leads to the incompleteness of this review study. Hence, future studies must 
extend the literature to all first-tier journals from both tourism and non-tourism areas in order to determine a more comprehensive view of the status quo of sustainable tourism research. Furthermore, because of the nature of JST, only English journal articles are analyzed, and an overt ignorance is exhibited with regard to conference articles, research notes, and the like in other languages. Therefore, the inclusion of literature from other sources is highly suggested. Finally, various methods utilized in current sustainable tourism studies are worth investigating, as these methods are the tools to realize the research objective and are quite important to an article.

Acknowledgments: This study is supported by The National Social Science Fund of China (Grants No. 17XMZ028).

Author Contributions: Jianwei Qian is the lead author on the publication, having done most of the writing for the paper. Huawen Shen contributed to the literature analysis as well as to the writing. Rob Law provided many suggestions and revised the whole paper.

Conflicts of Interest: The authors declare no conflict of interest. The funding sponsors had no role in the design of the study; in the collection, analyses, or interpretation of data; in the writing of the manuscript and in the decision to publish the results.

\section{References}

1. Lee, C.C.; Chang, C.P. Tourism development and economic growth: A closer look at panels. Tour. Manag. 2008, 29, 180-192. [CrossRef]

2. World Tourism Organization. Guide for Local Authorities on Developing Sustainable Tourism; WTO: Madrid, Spain, 1998; p. 9; ISBN 978-92-844-0280-9.

3. Beaumont, N. The Third criterion of ecotourism: Are ecotourism more concerned about sustainability than other tourists. J. Ecotourism 2011, 10, 135-148. [CrossRef]

4. Butzmann, E.; Job, H. Developing a typology of sustainable protected area tourism products. J. Sustain. Tour. 2017, 25, 1736-1755. [CrossRef]

5. Buckley, R. Sustainable tourism: Research and reality. Ann. Tour. Res. 2012, 39, 528-546. [CrossRef]

6. Ruhanen, L.; Weiler, B.; Moyle, B.D.; McLennan, C.L.J. Trends and patterns in sustainable tourism research: A 25-year bibliometric analysis. J. Sustain. Tour. 2015, 23, 517-535. [CrossRef]

7. Xiao, H.G.; Smith, S.L. The making of tourism research: Insights from a social sciences journal. Ann. Tour. Res. 2006, 33, 490-507. [CrossRef]

8. Sun, Y.; Wei, Y.J.; Zhang, L.Y. International academic impact of Chinese tourism research: A review based on the analysis of SSCI tourism articles from 2001 to 2012. Tour. Manag. 2017, 58, 245-252. [CrossRef]

9. Zheng, P.; Liang, X.; Huang, G.; Liu, X. Mapping the field of communication technology research in Asia: Content analysis and text mining of SSCI journal articles 1995-2014. Asian J. Commun. 2016, 26, 511-531. [CrossRef]

10. Nunkoo, R.; Smith, D.L.; Ramkissoon, H. Residents' attitudes to tourism: A longitudinal study of 140 articles from 1984 to 2010. J. Sustain. Tour. 2013, 21, 5-25. [CrossRef]

11. Lu, J.; Nepal, S.K. Sustainable tourism research: An analysis of papers published in the Journal of Sustainable Tourism. J. Sustain. Tour. 2009, 17, 5-16. [CrossRef]

12. Fong, L.H.N.; Law, R.; Tang, C.M.F.; Yap, M.H.T. Experiential research in hospitality and tourism: A critical review. Int. J. Contemp. Hosp. Manag. 2016, 28, 246-266. [CrossRef]

13. Mohammed, I.; Guillet, B.D.; Law, R. The contributions of economics to hospitality literature: A content analysis of hospitality and tourism journals. Int. J. Hosp. Manag. 2015, 44, 99-110. [CrossRef]

14. Xiao, H.G.; Smith, S.L. The use of tourism knowledge: Research propositions. Ann. Tour. Res. 2007, 34, 310-331. [CrossRef]

15. UNWTO. UNWTO Annual Report 2016. Available online: http://media.unwto.org/publication/unwtoannual-report-2016 (accessed on 12 December 2017).

16. Ye, Q.; Li, T.; Law, R. A coauthorship network analysis of tourism and hospitality research collaboration. J. Hosp. Tour. Res. 2013, 37, 51-76. [CrossRef]

17. Chen, C. CiteSpace II: Detecting and visualizing emerging trends and transient patterns in scientific literature. J. Assoc. Inf. Sci. Technol. 2006, 57, 359-377. [CrossRef] 
18. Chen, C. Predictive effects of structural variation on citation counts. J. Assoc. Inf. Sci. Technol. 2012, 63, 431-449. [CrossRef]

19. Piggott-McKellar, A.E.; McNamara, K.E. Last chance tourism and the Great Barrier Reef. J. Sustain. Tour. 2017, 25, 397-415. [CrossRef]

20. Font, X.; Elgammal, I.; Lamond, I. Greenhushing: The deliberate under communicating of sustainability practice by tourism businesses. J. Sustain. Tour. 2017, 25, 1007-1023. [CrossRef]

21. McKercher, B.; Mak, B.; Wong, S. Does climate change matter to the travel trade? J. Sustain. Tour. 2014, 22, 685-704. [CrossRef]

22. Hall, C.M.; Amelung, B.; Cohen, S.; Eijelaar, E.; Gossling, S.; Higham, J.; Scott, D. On climate change skepticism and denial in tourism. J. Sustain. Tour. 2015, 23, 4-25. [CrossRef]

23. Scott, D.; Simpson, M.C.; Sim, R. The vulnerability of Caribbean coastal tourism to scenarios of climate change related sea level rise. J. Sustain. Tour. 2012, 20, 883-898. [CrossRef]

24. Morrison, C.; Pickering, C.M. Perceptions of climate change impacts, adaptation and limits to adaptation in the Australian Alps: The ski-tourism industry and key stakeholders. J. Sustain. Tour. 2013, 21, 173-191. [CrossRef]

25. Steuger, R. Scenarios for skiing tourism in Austria: Integrating demographics with an analysis of climate change. J. Sustain. Tour. 2012, 20, 867-882. [CrossRef]

26. Dawson, J.; Stewart, E.J.; Lemelin, H.; Scott, D. The carbon cost of polar bear viewing tourism in Churchill, Canada. J. Sustain. Tour. 2010, 18, 319-336. [CrossRef]

27. Lambert, E.; Hunter, C.; Pierce, G.J.; MacLeod, C.D. Sustainable whale-watching tourism and climate change: Towards a framework of resilience. J. Sustain. Tour. 2010, 18, 409-427. [CrossRef]

28. Scott, D.; Hall, C.M.; Gossling, S. A report on the pair Climate Change Agreement and its implications for tourism: Why we will always have Paris. J. Sustain. Tour. 2016, 24, 933-948. [CrossRef]

29. Cohen, S.A.; Gooch, M. Sociological barriers to developing sustainable discretionary air travel behavior. J. Sustain. Tour. 2013, 21, 982-998. [CrossRef]

30. Juvan, E.; Dolnicar, S. Can Tourists easily choose a low carbon footprint vacation? J. Sustain. Tour. 2014, 22, 175-194. [CrossRef]

31. Mair, J. Exploring air travelers' voluntary carbon-offsetting behavior. J Sustain. Tour. 2011, 19, $215-230$. [CrossRef]

32. Segerstedt, A.; Grote, U. Increasing adoption of voluntary carbon offsets among tourists. J. Sustain. Tour. 2016, 24, 1541-1554. [CrossRef]

33. Choi, A.S.; Ritchie, B.W. Willingness to pay for flying carbon neutral in Australia: An exploratory study of offsetter profiles. J. Sustain. Tour. 2014, 22, 1236-1256. [CrossRef]

34. Buchs, M. The role of values for voluntary reductions of holiday air travel. J. Sustain. Tour. 2017, 25, 234-250. [CrossRef]

35. Font, X.; Hindley, A. Understanding tourists' reactance to the threat of a loss of freedom to travel due to climate change: A new alternative approach to encouraging nuanced behavioral change. J. Sustain. Tour. 2017, 25, 26-42. [CrossRef]

36. Dillimono, H.D.; Dickinson, J.E. Travel, tourism, climate change, and behavioral change: Travelers' perspectives from a developing country, Nigeria. J. Sustain. Tour. 2015, 23, 437-454. [CrossRef]

37. Scott, D. Why sustainable tourism must address climate change. J. Sustain. Tour. 2011, 19, 17-34. [CrossRef]

38. Hanna, P.; Scarles, C.; Cohen, S.; Adams, M. Everyday climate discourses and sustainable tourism. J. Sustain. Tour. 2016, 24, 1624-1640. [CrossRef]

39. Hopkins, D. The sustainability of climate change adaptation strategies in New Zealand's ski industry: A range of stakeholder perceptions. J. Sustain. Tour. 2014, 22, 107-126. [CrossRef]

40. Jones, C. Scenarios for greenhouse gas emissions reduction from tourism: An extended tourism satellite account approach in a regional setting. J. Sustain. Tour. 2013, 21, 458-472. [CrossRef]

41. Hu, M.L.; Horng, J.S.; Teng, C.C.; Chou, S.F. A critical model of restaurant energy conservation and carbon reduction in Taiwan. J. Sustain. Tour. 2013, 21, 765-779. [CrossRef]

42. Ram, Y.; Nawijn, J.; Peeters, P.M. Happiness and limits to sustainable tourism mobility: A new conceptual model. J. Sustain. Tour. 2013, 21, 1017-1035. [CrossRef]

43. Lin, C.P. Industrial tourists' behavioral intention toward slow travel in Taiwan. J. Sustain. Tour. 2017, 25, 379-396. [CrossRef] 
44. Nunkoo, R.; Gursoy, D.; Juwaheer, T.D. Island residents' identities and their support for tourism: An integration of two theories. J. Sustain. Tour. 2010, 18, 675-693. [CrossRef]

45. Rutty, M.; Mattews, L.; Scott, D.; Matto, T.D. Using vehicle monitoring technology and eco-driver training to reduce fuel use and emissions in tourism: A ski resort case study. J. Sustain. Tour. 2014, 22, 787-800. [CrossRef]

46. Hall, C.M. Intervening in academic interventions: Framing social marketing's potential for successful sustainable tourism behavioral change. J. Sustain. Tour. 2016, 24, 350-375. [CrossRef]

47. Kil, N.; Holland, S.M.; Stein, T.V.; Ko, Y.J. Place attachment as a mediator of the relationship between nature-based recreation benefits and future visit intentions. J. Sustain. Tour. 2012, 20, 603-626. [CrossRef]

48. Lee, T.H. How recreation involvement, place attachment and conservation commitment affect environmentally responsible behavior. J. Sustain. Tour. 2011, 19, 895-915. [CrossRef]

49. Dief, M.E.; Font, X. The determinants of hotels' marketing managers' green marketing behavior. J. Sustain. Tour. 2010, 18, 157-174. [CrossRef]

50. Lee, J.S.; Hsu, L.T.; Han, H.; Kim, Y. Understanding how consumers view green hotels: How a hotel's green image can influence behavioral intentions. J. Sustain. Tour. 2010, 18, 901-914. [CrossRef]

51. Kim, Y.; Han, H. Intention to pay conventional-hotel prices at a green hotel-a modification of the theory of planned behavior. J. Sustain. Tour. 2010, 18, 997-1014. [CrossRef]

52. Bohdanowicz, P.; Zientara, P.; Novotna, E. International hotel chains and environmental protection: An analysis of Hilton's we care! Pogram (Europe, 2006-2008). J. Sustain. Tour. 2011, 19, 797-816. [CrossRef]

53. Synman, S.L. The role of tourism employment in poverty reduction and community perceptions of conservation and tourism in southern Africa. J. Sustain. Tour. 2012, 20, 395-416. [CrossRef]

54. Erskine, L.M.; Meyer, D. Influenced and influential: The role of tour operators and development organizations in tourism and poverty reduction in Ecuador. J. Sustain. Tour. 2012, 20, 339-357. [CrossRef]

55. Tucker, H.; Boonabaana, B. A critical analysis of tourism, gender and poverty reduction. J. Sustain. Tour. 2012, 20, 437-455. [CrossRef]

56. Hummel, J.; van der Duim, R. Tourism and development at work: 15 years of tourism and poverty reduction within the SNV Netherlands Development Organization. J. Sustain. Tour. 2012, 20, 319-339. [CrossRef]

57. Nelson, F. Blessing or curse? The political economy of tourism development in Tanzania. J. Sustain. Tour. 2012, 20, 359-375. [CrossRef]

58. Truong, V.D.; Hall, C.M.; Garry, T. Tourism and poverty alleviation: Perceptions and experiences of poor people in Sapa, Vietnam. J. Sustain. Tour. 2014, 22, 1071-1089. [CrossRef]

59. Gascon, J. The limitations of community-based tourism as an instrument of development cooperation: The value of the Social Vocation of the Territory concept. J. Sustain. Tour. 2013, 21, 716-731. [CrossRef]

60. Spenceley, A.; Meyer, D. Tourism and poverty reduction: Theory and practice in less economically developed countries. J. Sustain. Tour. 2012, 20, 297-317. [CrossRef]

61. Medina-Munoz, D.R.; Medina-Munoz, R.D.; Gutierrez-Perez, F.J. The impacts of tourism on poverty alleviation: An integrated research framework. J. Sustain. Tour. 2016, 24, 270-298. [CrossRef]

62. Dillette, A.K.; Douglas, A.C.; Martin, D.S.; O'Neil, M. Resident perceptions on cross-cultural understanding as an outcome of volunteer tourism programs: The Bahamian Family Island perspective. J. Sustain. Tour. 2017, 25, 1222-1239. [CrossRef]

63. Hammersley, L.A. Volunteer tourism: Building effective relationships of understanding. J. Sustain. Tour. 2014, 22, 855-873. [CrossRef]

64. Raymond, E.M.; Hall, C.M. The development of cross-cultural (mis) understanding through volunteer tourism. J. Sustain. Tour. 2008, 16, 530-543. [CrossRef]

65. Brondo, K.V. The spectacle of saving: Conservation voluntourism and the new neoliberal economy on Utila, Honduras. J. Sustain. Tour. 2015, 23, 1405-1425. [CrossRef]

66. McGehee, N.G.; Andereck, K. Volunteer tourism and the 'voluntoured': The case of Tijuana, Mexico. J. Sustain. Tour. 2009, 17, 39-51. [CrossRef]

67. Coghlan, A.; Gooch, M. Applying a transformative learning framework to volunteer tourism. J. Sustain. Tour. 2011, 19, 713-728. [CrossRef]

68. Steele, J.; Dredge, D.; Scherrer, P. Monitoring and evaluation practices of volunteer tourism organizations. J. Sustain. Tour. 2017, 25, 1674-1690. [CrossRef] 
69. Lupoli, C.A.; Morse, W.C.; Bailey, C.; Schelhas, J. Assessing the impacts of international volunteer tourism in host communities: A new approach to organizing and prioritizing indicators. J. Sustain. Tour. 2014, 22, 898-921. [CrossRef]

70. Weaver, D. Volunteer tourism and beyond: Motivations and barriers to participation in protected area enhancement. J. Sustain. Tour. 2015, 23, 683-705. [CrossRef]

71. Lupoli, C.A.; Morse, W.C.; Bailey, C.; Schelhas, J. Indicator development methodology for volunteer tourism in host communities: Creating a low-cost, locally applicable, rapid assessment tool. J. Sustain. Tour. 2015, 23, 726-747. [CrossRef]

72. Smith, V.L.; Font, X. Volunteer tourism, greenwashing and understanding responsible marketing using market signaling theory. J. Sustain. Tour. 2014, 22, 942-963. [CrossRef]

73. Zahra, A.L. Rethinking regional tourism governance: The principle of subsidiarity. J. Sustain. Tour. 2011, 19, 535-552. [CrossRef]

74. Mitchell, J. Value chain approaches to assessing the impact of tourism on low-income household in developing countries. J. Sustain. Tour. 2012, 20, 457-475. [CrossRef]

75. Fletcher, C.; Pforr, C.; Brueckner, M. Factors influencing indigenous engagement in tourism development: An international perspective. J. Sustain. Tour. 2016, 24, 1100-1120. [CrossRef]

76. Whitford, M.M.; Ruhanen, L.M. Australian indigenous tourism policy: Practical and sustainable policies? J. Sustain. Tour. 2010, 18, 475-496. [CrossRef]

77. Csete, M.; Szecsi, N. The role of tourism management in adaptation to climate change-a study of a European inland area with a diversified tourism supply. J. Sustain. Tour. 2015, 23, 477-496. [CrossRef]

78. Hall, C.M. A typology of governance and its implications for tourism policy analysis. J. Sustain. Tour. 2011, 19, 437-457. [CrossRef]

79. Yuksel, A.; Yuksel, F.; Culha, O. Ministers' statements: A policy implementation instrument for sustainable tourism? J. Sustain. Tour. 2012, 20, 513-532. [CrossRef]

80. Strickland-Munro, J.; Moore, S. Indigenous involvement and benefits from tourism in protected areas: A study of Purnululu National Park and Warmun Community, Australia. J. Sustain. Tour. 2013, 21, $26-41$. [CrossRef]

81. Weaver, D. Indigenous tourism stages and their implications for sustainability. J. Sustain. Tour. 2010, 18, 43-60. [CrossRef]

82. Buultjens, J.; Gale, D.; White, N.E. Synergies between Australian indigenous tourism and ecotourism: Possibilities and problems for future development. J. Sustain. Tour. 2010, 18, 497-513. [CrossRef]

83. Scherrer, P.; Doohan, K. Taming wicked problems: Towards a resolution of tourism access to traditional owner lands in the Kimberley region, Australia. J. Sustain. Tour. 2014, 22, 1003-1022. [CrossRef]

84. Jamal, T.; Camargo, B.A. Sustainable tourism, justice and an ethic of care: Toward the just destination. J. Sustain. Tour. 2014, 22, 11-30. [CrossRef]

85. Esparon, M.; Stoeckl, N.; Farr, M.; Larson, S. The significance of environmental values for destination competitiveness and sustainable tourism strategy making: Insights from Australia's Great Barrier Reef World Heritage Area. J. Sustain. Tour. 2015, 23, 706-725. [CrossRef]

86. Ramos, A.M.; Prideaux, B. Indigenous ecotourism in the Mayan rainforest of Palenque: Empowerment issues in sustainable development. J. Sustain. Tour. 2014, 22, 461-479. [CrossRef]

87. Hillmer-Pegram, K. Integrating indigenous values with capitalism through tourism: Alaskan experiences and outstanding issues. J. Sustain. Tour. 2016, 24, 1194-1210. [CrossRef]

88. Park, E.; Boo, S. An assessment of convention tourism's potential contribution to environmentally sustainable growth. J. Sustain. Tour. 2010, 18, 95-113. [CrossRef]

(C) 2018 by the authors. Licensee MDPI, Basel, Switzerland. This article is an open access article distributed under the terms and conditions of the Creative Commons Attribution (CC BY) license (http://creativecommons.org/licenses/by/4.0/). 